\title{
The influence of promoter polymorphism of nuclear factor-erythroid 2-related factor 2 gene on the aberrant DNA methylation in gastric epithelium
}

\author{
TOMIYASU ARISAWA, TOMOMITSU TAHARA, TOMOYUKI SHIBATA, MITSUO NAGASAKA, \\ MASAKATSU NAKAMURA, YOSHIO KAMIYA, HIROSHI FUJITA, DAISUKE YOSHIOKA, \\ YUKO ARIMA, MASAAKI OKUBO, ICHIRO HIRATA and HIROSHI NAKANO
}

Department of Gatroenterology, Fujita Health University, School of Medicine, 1-98, Dengakugakubo, Kutsukake-cho, Toyoake 470-1192, Japan

Received June 7, 2007; Accepted August 13, 2007

\begin{abstract}
Aberrant promoter methylation is an important mechanism for gene silencing. Inflammation-related reactive oxygens contribute to this $\mathrm{CpG}$ island methylation. The nuclear factor-erythroid 2-related factor 2 gene (Nrf2) is known to regulate the expression of detoxifying and antioxidant genes. We investigated the relationship between promoter polymorphisms of Nrf2 gene and the $\mathrm{CpG}$ island methylation in non-cancerous gastric mucosa. The study was performed in 85 subjects (46 without gastric malignancies, non-GC group, and 39 with gastric cancer, GC group). The promoter methylation status of p14(ARF), p16(INK4a) and p21(Waf1) genes was determined by methylation-specific-polymerase chain reaction. The Nrf2 gene genotypes were determined by the PCR-SSCP method. In the 85 subjects, $\mathrm{CpG}$ island methylation was found in $25.9 \%$ for $\mathrm{p} 14,15.3 \%$ for $\mathrm{p} 16$, none for $\mathrm{p} 21$. The frequency of the methylated genes was significantly higher in GC group than non-GC group (OR, 2.67; 95\% CI, $1.10-6.49 ; \mathrm{p}=0.029)$. In particular, the frequency of $\mathrm{p} 16$ gene methylation was much higher in GC group $(\mathrm{p}=0.0023)$. The Nrf2 -686/-684 G/G haplotype was positively associated and $\mathrm{A} / \mathrm{G}$ haplotype was inversely associated with the development of CpG island methylation, especially p14 gene methylation (OR, 3.28; 95\% CI, 1.26-8.59; $\mathrm{p}=0.015$, and OR, 0.38; $95 \%$ CI, 0.15-0.96; p=0.040, respectively). In Helicobacter pylori (H. pylori) infected subjects, the number of $-686 /-684 \mathrm{G} / \mathrm{G}$ allele was positively correlated and that of $A / G$ allele was inversely correlated to the methylation status, especially p14 methylation, by the adjusted analysis (OR, 2.90; 95\% CI,
\end{abstract}

Correspondence to: Dr Tomiyasu Arisawa, Department of Gatroenterology, Fujita Health University, School of Medicine, 1-98, Dengakugakubo, Kutsukake-cho, Toyoake 470-1192, Japan

E-mail: tarisawa@fujita-hu.ac.jp

Key words: nuclear factor-erythroid 2-related factor 2, promoter polymorphism, gastric cancer, aberrant DNA methylation, Helicobacter pylori
1.14-7.36; $\mathrm{p}=0.026$, and OR, 0.33; 95\% CI, 0.13-0.88; $\mathrm{p}=0.027$, respectively). Our results suggested that the promoter polymorphisms of Nrf2 gene may affect the methylation status of tumor-related genes, especially the p14 gene, under the influence of $H$. pylori-induced gastric inflammation.

\section{Introduction}

DNA methylation has been shown to be an important mechanism in gene silencing. Such $\mathrm{CpG}$ island methylation is commonly detected in human cancers $(1,2)$. Meanwhile, some genes are also methylated in non-neoplastic tissues with aging, and this alteration is known as age-related methylation $(3,4)$. It has also shown that gene methylation may be present in non-neoplastic colorectal mucosa in patients with inflammatory bowel desease $(5,6)$, esophageal mucosa in patients with Barrett's esophagitis $(7,8)$, and liver tissues in chronic hepatitis (9). In gastric carcinogenesis, DNA methylation of tumor-related genes has been shown to occur in early stage and it increases in parallel $(10,11)$. In addition, it was indicated that methylation of $\mathrm{CpG}$ island was induced by Helicobacter pylori $(H$.pylori) infection in non-cancerous mucosa $(12,13)$. These findings suggest that gene methylation could be a result of chronic inflammation, may be an early event in tumorigenesis, and the gene methylation would be expected to indicate an increased risk of tumor formation.

On the other hand, reactive oxygen species (ROS) produced by inflammatory cells are strongly involved in the carcinogenesis process. Involvement of inflammation-related ROS has been suggested in the etiology of human lung cancer (14). Weitzman et al reported that free radical injury may explain some of the altered methylation observed during carcinogenesis (15). Thus, ROS may influence the carcinogenesis during the chronic inflammation via inducing the aberrant DNA methylation. Recent studies have indicated that nuclear factor-erythroid 2-related factor 2 (Nrf2) is an important regulator of the genes induced by oxidative stress, such as heme oxygenase- 1 and peroxiredoxin 1 (16). In addition, susceptibility to hyperoxia is tightly linked to the nrf2 locus (17) and nrf2 null mice show impaired defenses against oxidative stress with substantially decreased clearance of ROS (18). The promoter region of the human Nrf2 gene 
has three known polymorphisms (positions, -686, -684 and -650) (19). We have already revealed that these polymorphisms were significantly associated with the development of gastric mucosal inflammation, as well as ulcerative colitis $(20,21)$. Then, we hypothesized the possibility that the Nrf2 polymorphisms influence the aberrant methylation of tumor suppressor genes, such as p14, p16 and p21 genes, in H.pylorirelated chronic gastritis.

In the present study, we investigated the relationship between promoter polymorphisms of the Nrf2 gene and the aberrant DNA methylation in non-cancerous gastric epithelium.

\section{Materials and methods}

Tissue samples, DNA extraction and Helicobacter Pylori infection status. The studied population comprised 85 subjects (46 with no malignant tumors and 39 with gastric cancer) recruited at the Endoscopy Center of Fujita Health University Hospital. All subjects underwent upper endoscopy with biopsy from non-cancerous mucosa in antrum. The specimens were immediately frozen and stored at $-80^{\circ} \mathrm{C}$. The patients with systemic severe diseases were excluded. Genomic DNA was isolated from frozen specimens using proteinase K. H. pylori infection status was assessed by serologic, histological analysis or urea breath test. Patients were diagnosed as infected when at least one of the diagnostic tests was positive.

The Ethics Committee of the Fujita Health University School of Medicine approved the protocol, and prior, written informed consent was obtained from all participating subjects.

Bisulfate modification and Methylation-Specific PCR (MSP). To examine DNA methylation, genomic DNA was treated with sodium bisulfite using BislFast DNA Modification Kit for methylated DNA detection (Toyobo, Co., Ltd., Osaka, Japan). MSP were carried out with primers as follows: p14(ARF) methylated: forward, 5'-tgagtttggttttggaggtgg-3'; reverse, 5'-aaaaccacaacgacgaacg-3'. p14(ARF) unmethylated: forward, 5'-gagtttggttttggaggtgg-3'; reverse, 5'-aaccacaacaa caaacaccct-3'. p16(INK4a) methylated: forward, 5'-ttattagag ggtggggcggatcgc-3'; reverse, 5'-acccegaaccgcgaccgtaa-3'. p16(INK4a) unmethylated: forward, 5'-ttattagagggtgggg tggattgt-3'; reverse, 5'-caaccccaaaccacaaccataa-3'. p21(Waf1) methylated: forward, 5'-tgtagtacgcgaggtttcg-3'; reverse, 5'-tca actaacgcaactcaacg-3'. p21(Waf1) unmethylated: forward, 5'-tt tttgtagtatgtgaggtttgg-3'; reverse, 5'-aacacaactcaacacaacccta-3'.

The annealing temperature and times were determined using DNA from peripheral blood of a young individual without $H$. pylori infection and DNA methylated with SssI methylase (New England BioLabs Inc., Beverly, MA). The MSP was carried out in a volume of $20 \mu \mathrm{l}$ containing $0.1 \mu \mathrm{g}$ of bisulfite-modified DNA. The DNA was denatured at $95^{\circ} \mathrm{C}$ for $5 \mathrm{~min}$, followed by 33 cycles at $95^{\circ} \mathrm{C}$ for $30 \mathrm{sec}, 64-68^{\circ} \mathrm{C}$ according to primers for $1 \mathrm{~min}$, and $72^{\circ} \mathrm{C}$ for 1 min with a final extension at $72^{\circ} \mathrm{C}$ for $5 \mathrm{~min}$. MSP reactions were done using EX Taq HS (Takara Bio Inc., Shiga, Japan). The bands of MSP were detected by electrophoresis in 3.0\% agarose gels stained with ethdium bromide. With regard to the assessment for p16 gene methylation, the value of fluorescence intensities of methylated and unmethylated bands were measured by a digital densitometer. The methylation ratio, calculated as the ratio of this value of methylated band to methylated plus unmethylated bands, over $50 \%$ was estimated as significantly methylated. The subjects were divided into the following 2 groups: the methylated group (either p14 or p16 gene was methylated) and the unmethylated group (neither p14 nor p16 genes were not methylated).

Genotyping of Nrf2 polymorphisms. Nrf2 polymorphisms were genotyped by PCR-SSCP as reported previously $(20,21)$. We employed the nested PCR reaction because the quality of the PCR-SSCP depends on the purity of the reactants. Primer sequences for the PCRs are as follows: 1st PCR forward, 5'aaacgattacagcatgttgtggt-3' (NRF2F); reverse, 5'-tgatttggagttg cagaacctt-3' (NRF2R). 2nd PCR for -686/-684: forward, 5'gctctgggtgggcaatactg-3' (NRF2-AF); reverse, 5'-cgcagtcaccet gaacgc-3' (NRF2-AR) and for -650: forward, 5'-tgactgcgaaca cgagctg-3' (NRF2-BF); reverse, 5'-ggctaaagatttggacccagac-3' (NRF2-BR).

The first PCR was carried out using a pair of primers (NRF2F and NRF2R) in a volume of $20 \mu \mathrm{l}$ containing $0.1 \mu \mathrm{g}$ of genomic DNA. The DNA was denatured at $95^{\circ} \mathrm{C}$ for $5 \mathrm{~min}$, followed by 35 cycles of $95^{\circ} \mathrm{C}$ for $30 \mathrm{sec}, 62^{\circ} \mathrm{C}$ for $40 \mathrm{sec}$ and $72^{\circ} \mathrm{C}$ for $60 \mathrm{sec}$, with final extension at $72^{\circ} \mathrm{C}$ for $5 \mathrm{~min}$. The second PCR was carried out in a volume of $20 \mu \mathrm{l}$ containing $2 \mu 1$ of the first PCR product diluted 100-fold with distilled water as a sample using two pairs of primers (NRF2-AF, -AR and NRF2-BF, -BR for bases -686/-684 and -650, respectively). The DNA was denatured at $95^{\circ} \mathrm{C}$ for $5 \mathrm{~min}$, followed by 35 cycles of $95^{\circ} \mathrm{C}$ for $15 \mathrm{sec}, 62^{\circ} \mathrm{C}$ for $30 \mathrm{sec}$ and $72^{\circ} \mathrm{C}$ for $45 \mathrm{sec}$, with final extension at $72^{\circ} \mathrm{C}$ for $5 \mathrm{~min}$.

Then $2 \mu \mathrm{l}$ of the 2 nd PCR product was denatured with $10 \mu 1$ of formamide (Sigma-Aldrich Co., St. Louis, USA) for 5 min at $90^{\circ} \mathrm{C}$. SSCP was carried out at 6 or $18^{\circ} \mathrm{C}$ using a GenePhor DNA separation system with GeneGel Excel 12.5/24 (Amersham Biosciences Corp., USA). The denatured single-stranded DNA bands were detected using a DNA Silver Staining Kit (Amersham Biosciences Corp.).

Statistical analysis. Mean ages between two groups were compared with Student's t-test. The ratio of gender, H. pylori positivity and DNA methylation were compared using $\chi^{2}$ test. The allele counts were also compared between the methylated group and the unmethylated group by a $2 \times 2$ table using $\chi^{2}$ test. The strength of association between allele frequencies and the disease was assessed by calculating the odds ratio (OR) and 95\% confidence intervals (CI). Adjusted ORs were calculated with the use of a regression analysis after adjustment for age, gender and $H$. pylori infection status. For all analyses, the level of significance was set at $\mathrm{p}<0.05$.

\section{Results}

Subjects. A total of 46 non-cancer patients (non-GC) and 39 gastric cancer patients (GC) participated in this study. The characteristics are summarized in Table I. There was no significant difference between the two groups in the distribution of age and sex, while $H$. pylori positivity was significantly higher in GC group ( $\mathrm{p}=0.0007)$. 
Table I. Characteristics of the subjects and frequencies of gene methylation.

\begin{tabular}{|c|c|c|c|c|c|}
\hline & Overall & Non-GC & $\mathrm{GC}$ & OR $(95 \% \mathrm{CI})$ & P-value \\
\hline No. of subjects & 85 & 46 & 39 & & \\
\hline Mean age \pm SD & $65.6 \pm 11.3$ & $65.2 \pm 12.9$ & $66.2 \pm 9.7$ & NS & \\
\hline Male/Female & $59 / 26$ & $32 / 14$ & $27 / 12$ & NS & \\
\hline H. pylori positivity & $61 / 85$ & $26 / 46$ & $35 / 39$ & $6.73(2.05-22.1)$ & 0.0007 \\
\hline p14 or p16 gene & $35 / 85$ & $14 / 46$ & $21 / 39$ & $2.67(1.10-6.49)$ & 0.029 \\
\hline p14 gene $^{\mathrm{a}}$ & $22 / 85$ & $12 / 46$ & $10 / 39$ & NS & \\
\hline p16 gene ${ }^{a}$ & $13 / 85$ & $2 / 46$ & $11 / 39$ & 8.64 (1.78-41.9) & 0.0023 \\
\hline
\end{tabular}

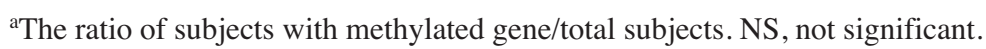

Table II. The frequencies of genotypes among methylated and unmethylated groups.

\begin{tabular}{|c|c|c|c|c|}
\hline & Unmethylated (\%) & Methylated (\%) & OR $(95 \% \mathrm{CI})$ & P-value \\
\hline No. of subjects & 50 & 35 & & \\
\hline Mean age \pm SD & $64.3 \pm 11.9$ & $67.6 \pm 10.6$ & NS & \\
\hline Male/Female & $35 / 15$ & $24 / 11$ & NS & \\
\hline H.pylori positivity & $31 / 50$ & $30 / 35$ & $3.68(1.22-11.1)$ & 0.017 \\
\hline Non-GC/GC & $32 / 18$ & $14 / 21$ & $2.67(1.10-6.49)$ & 0.029 \\
\hline \multicolumn{5}{|l|}{$-686 /-684$ haplotype } \\
\hline GG/GG & 10 & 16 & & \\
\hline $\mathrm{GG} / \mathrm{AG}$ & 24 & 12 & & \\
\hline GG/AA & 3 & 1 & & \\
\hline $\mathrm{AG} / \mathrm{AG}$ & 7 & 6 & & \\
\hline AG/AA & 5 & 0 & & \\
\hline$-686 \mathrm{~A}$ allele frequency & 52.0 & 35.7 & $0.51(0.27-0.96)$ & 0.036 \\
\hline$-684 \mathrm{~A}$ allele frequency & 8.2 & 1.4 & NS & \\
\hline \multicolumn{5}{|l|}{-650 genotype } \\
\hline $\mathrm{C} / \mathrm{C}$ & 24 & 20 & & \\
\hline $\mathrm{C} / \mathrm{A}$ & 24 & 13 & & \\
\hline $\mathrm{A} / \mathrm{A}$ & 2 & 2 & & \\
\hline$-650 \mathrm{~A}$ allele frequency & 28.0 & 24.3 & NS & \\
\hline
\end{tabular}

NS, not significant. One case in the unmethylated group could not be genotyped at positions -686/-684

The methylation of p21 gene was not detected in all subjects. $\mathrm{CpG}$ island methylation of tumor-related genes was found in $41.2 \%$ (25.9\% for p14 and $15.3 \%$ for $\mathrm{p} 16)$. The frequency of $\mathrm{CpG}$ methylation was significantly higher in $\mathrm{GC}$ group than non-GC group ( $\mathrm{p}=0.029)$. The higher frequency of p16 gene was found in GC group compared with non-GC group, whereas there was no significant difference of the methylation frequency of p14 gene among the GC and nonGC groups.

The frequencies of genotypes of Nrf2 gene among the methylated and unmethylated groups. There were no significant differences between the methylated and unmethylated groups in the distribution of age and sex, while $H$. pylori positivity was significantly higher in the methylated group than the unmethylated group $(p=0.017$, Table II). The frequency of the patients with gastric cancer was also significantly higher in the methylated group $(\mathrm{p}=0.029)$.

The frequency of Nrf2 gene -686A allele was significantly higher in the unmethylated group than the methylated group $(\mathrm{p}=0.036)$, whereas the frequencies of $-684 \mathrm{~A}$ and $-650 \mathrm{~A}$ alleles were not significant different between the groups.

The influence of the Nrf2 gene polymorphisms on the CpG island methylation. By unadjusted analyses, the number of $-686 /-684$ G/G allele was positively correlated to the CpG 
Table III. The risk of the Nrf2 gene polymorphisms for CpG island methylation.

\begin{tabular}{|c|c|c|c|c|c|c|}
\hline & \multicolumn{2}{|c|}{ Overall methylation } & \multicolumn{2}{|c|}{ p14 gene methylation } & \multicolumn{2}{|c|}{ p16 gene methylation } \\
\hline & Unadjusted & Adjusted $^{\mathrm{a}}$ & Unadjusted & Adjusted $^{\mathrm{a}}$ & Unadjusted & Adjusted $^{\mathrm{a}}$ \\
\hline $\begin{array}{l}-686 /-684 \mathrm{G} / \mathrm{G} \\
\text { allele }^{\mathrm{b}}\end{array}$ & $1.94(1.02-3.68)^{\mathrm{c}}$ & $1.59(0.80-3.17)$ & $1.85(0.90-3.80)$ & $1.71(0.80-3.66)$ & $1.66(0.70-3.95)$ & $1.19(0.43-3.29)$ \\
\hline $\begin{array}{l}-686 /-684 \text { A/G } \\
\text { allele }^{b}\end{array}$ & $0.66(0.35-1.26)$ & $0.84(0.42-1.67)$ & $0.62(0.29-1.30)$ & $0.66(0.31-1.43)$ & $0.76(0.32-1.85)$ & $1.26(0.47-3.43)$ \\
\hline $\begin{array}{l}-686 /-684 \mathrm{G} / \mathrm{G} \\
\text { homozygote }\end{array}$ & $3.28(1.26-8.59)^{\mathrm{d}}$ & $1.04(0.32-3.41)$ & $3.13(1.13-8.67)^{\mathrm{f}}$ & $2.87(0.97-8.47)$ & $2.19(0.65-7.31)$ & $1.76(0.45-6.80)$ \\
\hline $\begin{array}{l}-686 /-684 \text { A/G } \\
\text { carrier }\end{array}$ & $0.38(0.15-0.96)^{\mathrm{e}}$ & $0.52(0.20-1.38)$ & $0.34(0.13-0.93)^{\mathrm{g}}$ & $0.37(0.13-1.08)$ & $0.60(0.18-1.97)$ & $1.02(0.27-3.84)$ \\
\hline $\begin{array}{l}-650 \mathrm{C} / \mathrm{C} \\
\text { homozygote }\end{array}$ & $1.44(0.61-3.45)$ & $1.19(0.47-3.02)$ & $1.16(0.44-3.08)$ & $1.01(0.37-2.78)$ & $1.60(0.48-5.36)$ & $1.31(0.35-4.95)$ \\
\hline
\end{tabular}

${ }^{a}$ Adjusted for the age, gender and $H$. pylori infection status. ${ }^{\mathrm{b}}$ Analysis using the number of each allele as a co-variate. P-value: 0.044 , ${ }^{\mathrm{d}} 0.015,{ }^{\mathrm{e}} 0.040,{ }^{\mathrm{f}} 0.028,{ }^{\mathrm{g}} 0.035$.

island methylation status (OR, 1.94; 95\% CI, 1.02-2.68; $\mathrm{p}=0.044)$. In addition, $-686 /-684 \mathrm{G} / \mathrm{G}$ homozygous genotype had an increased risk (OR, 3.28; 95\% CI, 1.26-8.59; $\mathrm{p}=0.015)$ and $-686 /-684 \mathrm{~A} / \mathrm{G}$ carriers had a reduced risk (OR, 0.38; 95\% CI, 0.15-0.96; $\mathrm{p}=0.040$ ) for the development of $\mathrm{CpG}$ island methylation, especially p14 gene methylation. However, there were no significant associations between the Nrf2 gene polymorphisms and the $\mathrm{CpG}$ island methylation by the adjusted analyses (Table III).

No significant relationship was found between C-650A polymorphism of $\mathrm{Nrf} 2$ gene and $\mathrm{CpG}$ island methylation status.

The risk of Nrf2 gene polymorphisms for CpG island methylation in $H$. pylori positive subjects. Because a significant interactions between $H$. pylori infection and -686/-684 genotype $(\mathrm{G} / \mathrm{G}$ allele, $\mathrm{p}=0.050$ and $\mathrm{A} / \mathrm{G}$ allele, $\mathrm{p}=0.012)$ by Ancova using the number of each allele as co-variate, the analysis was performed in $H$. pylori infected subjects. As shown in Table IV, the number of $-686 /-684 \mathrm{G} / \mathrm{G}$ allele was positively correlated to the degree of the $\mathrm{CpG}$ island methylation. In addition, -686/-684 G/G homozygous genotype had an increased risk for the development of $\mathrm{CpG}$ island methylation by unadjusted and adjusted analyses (OR, 3.29; 95\% CI, 1.12-9.66; $\mathrm{p}=0.031$, and OR, 3.24; 95\% CI, 1.09-9.61; $\mathrm{p}=0.034$, respectively).

There were no significant associations between the Nrf2 gene polymorphisms and p16 gene methylation. However, the number of $-686 /-684 \mathrm{G} / \mathrm{G}$ allele was positively correlated and that of $\mathrm{A} / \mathrm{G}$ allele was inversely correlated to the development of p14 gene methylation (OR, 2.90; 95\% CI, 1.14-7.36; $\mathrm{p}=0.026$, and OR, 0.33; 95\% CI, 0.13-0.88; $\mathrm{p}=0.027$, respectively). Furthermore, -686/-684 G/G homozygous genotype had an increased risk and $\mathrm{A} / \mathrm{G}$ carriers had a reduced risk for the development of p14 gene methylation (OR, 3.66;
95\% CI, 1.14-11.8; $\mathrm{p}=0.030$, and OR, 0.25; 95\% CI, 0.075$0.83 ; \mathrm{p}=0.023$, respectively). There were no significant associations between the Nrf2 C-650A polymorphism and the $\mathrm{CpG}$ island methylation status.

\section{Discussion}

In the present study, we investigated the association between the Nrf2 gene polymorphisms and the degree of $\mathrm{CpG}$ island methylation in non-cancerous gastric mucosa. We found that $-686 /-684$ G/G genotype was positively associated and A/G genotype was inversely associated with the development of CpG island methylation, especially p14 gene methylation in $H$. pylori infected subjects.

The p16(INK4a) and p14(ARF) are involved in the negative cell cycle regulation via the $\mathrm{pRb}$ and $\mathrm{p} 53$ pathways, respectively. These two proteins have an independent first exon (exon $1 \alpha$ and $1 \beta$, respectively) but share exon 2 and 3 $(22,23)$. Aberrant promoter methylation is an important mechanism for gene silencing. Methylation of p16 and p14 genes has been shown to be present in gastric cancer as well as premalignant lesions $(24,25)$. The p21(Waf1) is also involved in cell cycle arrest (26), which is up-regulated in $H$. pylori infection $(27,28)$. These genes may play crucial roles in cell cycle control, apoptosis and DNA repair in the stomach and its disorder may be closely associated with gastric carcinogenesis. In our study, the frequency of the $\mathrm{CpG}$ island methylation in non-cancerous gastric mucosa was significantly higher in the subjects with gastric cancer compared with the subjects without gastric cancer. In particular, the frequency of p16 gene methylation was much higher $(p=0.0023)$ and $p 21$ gene methylation was not detected. A previous study suggested that tumor suppressor genes showed a gene type-specific methylation profile and that aberrant $\mathrm{CpG}$ island methylation tended to accumulate 
Table IV. The risk of the Nrf2 gene polymorphisms for CpG island methylation in H. pylori infected subjects.

\begin{tabular}{|c|c|c|c|c|c|c|}
\hline & \multicolumn{2}{|c|}{ Overall methylation } & \multicolumn{2}{|c|}{ p14 gene methylation } & \multicolumn{2}{|c|}{ p16 gene methylation } \\
\hline & Unadjusted & Adjusted $^{\mathrm{a}}$ & Unadjusted & Adjusted $^{\mathrm{a}}$ & Unadjusted & Adjusted $^{\mathrm{a}}$ \\
\hline $\begin{array}{l}-686 /-684 \mathrm{G} / \mathrm{G} \\
\text { allele }^{\mathrm{b}}\end{array}$ & $2.25(1.03-4.93)^{\mathrm{c}}$ & $2.20(1.00-4.87)$ & $2.83(1.11-7.20)^{\mathrm{f}}$ & $2.90(1.14-7.36)^{\mathrm{j}}$ & $1.26(0.50-3.21)$ & $1.09(0.39-3.08)$ \\
\hline $\begin{array}{l}-686 /-684 \text { A/G } \\
\text { allele }\end{array}$ & $0.51(0.24-1.11)$ & $0.53(0.24-1.17)$ & $0.36(0.14-0.93)^{\mathrm{g}}$ & $0.33(0.13-0.88)^{\mathrm{k}}$ & $0.94(0.38-2.37)$ & $1.27(0.45-3.56)$ \\
\hline $\begin{array}{l}-686 /-684 \mathrm{G} / \mathrm{G} \\
\text { homozygote }\end{array}$ & $3.29(1.12-9.66)^{\mathrm{d}}$ & $3.24(1.09-9.61)^{\mathrm{e}}$ & $3.63(1.15-11.4)^{\mathrm{h}}$ & $3.66(1.14-11.8)^{1}$ & $1.72(0.48-6.15)$ & $1.77(0.46-6.83)$ \\
\hline $\begin{array}{l}-686 /-684 \text { A/G } \\
\text { carrier }\end{array}$ & $0.36(0.13-1.03)$ & $0.38(0.13-1.11)$ & $0.27(0.084-0.86)^{\mathrm{i}}$ & $0.25(0.075-0.83)^{\mathrm{m}}$ & $0.75(0.21-2.66)$ & $0.92(0.24-3.55)$ \\
\hline $\begin{array}{l}-650 \mathrm{C} / \mathrm{C} \\
\text { homozygote }\end{array}$ & $1.88(0.67-5.28)$ & $1.92(0.67-5.48)$ & $1.58(0.50-5.00)$ & $1.64(0.51-5.28)$ & $1.50(0.40-5.66)$ & $1.54(0.38-6.23)$ \\
\hline
\end{tabular}

${ }^{\mathrm{a}}$ Adjustment for the age and gender. ${ }^{\mathrm{b}}$ Analysis using the number of each allele as a co-variate. P-value: ${ }^{\mathrm{c}} 0.043,{ }^{\mathrm{d}} 0.031,{ }^{\mathrm{e}} 0.034,{ }^{\mathrm{f}} 0.029,{ }^{\mathrm{g}} 0.035$, ${ }^{\mathrm{h}} 0.028,{ }^{\mathrm{i}} 0.027,{ }^{\mathrm{j}} 0.026,{ }^{\mathrm{k}} 0.027,{ }^{\mathrm{l}} 0.030,{ }^{\mathrm{m}} 0.023$.

along the pathway of multistep carcinogenesis (11). Our results also suggested that $\mathrm{CpG}$ island methylation was associated with gastric carcino-genesis (OR, 2.67; 95\% CI, 1.09-9.61; $\mathrm{p}=0.029)$.

Some genes are methylated with age (29) and chronic inflammation (30) in colorectal epithelium. In the stomach, aberrant $\mathrm{CpG}$ island hypermethylation of chronic gastritis is related with age, gender, intestinal metaplasia, and chronic inflammation (31). The stomach is one of the organs that shows frequent methylation of $\mathrm{CpG}$ islands of genes in noncancerous epithelial cells $(32,33)$. The mechanisms of age- or inflammation-related methylation are unknown. Several factors may contribute to this methylation, such as exogenous carcinogens, generated reactive oxygens, and host genetic differences (29). Endogenously generated reactive oxygen species, such as peroxides and oxygen-free radicals, may play an important role in carcinogenesis (34). Reactive oxygen species (ROS) are believed to be involved in the process of inflammation and the expression of oncogenes (35). H. pylori-induced expression of oncogenes and cell-cycle regulators may be mediated by ROS-induced activation of oxidant-sensitive transcription factors in gastric epithelial cells $(36,37)$. These oxidants also produce a variety of effects characteristic of carcinogens, including altered cytosine methylation (38). Weitzman et al reported that methylation of cytosine residues in DNA can be greatly influenced by hydroxyl-free radical adducts on adjacent guanine residues (15). Nrf2 is an important regulator of the genes induced by oxidative stress, such as heme oxygenase-1 and peroxiredoxin 1, and induces phase II detoxifying enzymes and antioxidant enzymes via Nrf2 acting on the antioxidant response elements (ARE) located in the 5'-flanking region of these enzyme genes. Therefore, it is entirely possible that polymorphisms of the Nrf2 gene affect the alteration of $\mathrm{CpG}$ island methylation.

We previously reported that -686/-684 G/G haplotype was associated with the increased inflammation severity $(20,21)$. In the present study, the frequency of $\mathrm{CpG}$ island methylation was higher in -686/-684 G/G genotype and significantly lower in $\mathrm{A} / \mathrm{G}$ genotype. This finding was more distinct in $H$. pylori infected subjects. One of the most important factors causing gastric inflammation is $H$. pylori infection $(39,40)$, under which gastric mucosa is suffering from various oxidative stress $(41,42)$. In $H$. pylori infected subjects, the effect of Nrf2 may be more apparent because of ROS produced abundantly by $H$. pylori infection.

In our study, Nrf2 promoter polymorphisms correlated to p14 gene methylation. On the other hand, gastric carcinogenesis was associated with p16 gene methylation, not p14 gene. Therefore, the alteration of methylation status affected by Nrf2 genotype may not directly contribute to gastric carcinogenesis. It is unknown why Nrf2 polymorphisms affect only p14 gene methylation, not p16 gene methylation. However, Iida et al revealed that p14(ARF) alterations might be involved in diffuse-type gastric carcinogenesis (43). With regard to this point, further studies will be needed. H. pylori infection has been reported to potently induce the methylation of $\mathrm{CpG}$ islands to various degrees (12). That is, there are marked interindividual differences in the degree of $\mathrm{CpG}$ island methylation among persons with $H$. pylori infection. Nrf2 polymorphisms may contribute to these interindividual differences and the subsequent development of gastric cancer.

In conclusions, the promoter polymorphisms of Nrf2 gene affect the methylation status of tumor-related genes, especially p14 gene, under the influence of $H$. pylori-induced gastric inflammation. Further studies are needed to clarify whether this influence of Nrf2 gene polymorphisms on the $\mathrm{CpG}$ island methylation lead to the gastric carcinogenesis or not.

\section{References}

1. Baylin SB, Herman JG, Graff JR, Vertino PM and Issa JP: Alterations in DNA methylation: a fundamental aspect of neoplasia. Adv Cancer Res 72: 141-196, 1998. 
2. Jones PA and Baylin SB: The fundamental role of epigenetic events in cancer. Nat Rev Genet 3: 415-428, 2002.

3. Issa JP, Ottaviano YL, Celano P, Hamilton SR, Davidson NE and Baylin SB: Methylation of the oestrogen receptor $\mathrm{CpG}$ island links ageing and neoplasia in human colon. Nat Genet 4: 536-540, 1994

4. Ahuja N, Li Q, Mohan AL, Baylin SB and Issa JP: Aging and DNA methylation in colorectal mucosa and cancer. Cancer Res 23: 5489-5494, 1998.

5. Sato F, Harpaz N, Shibata D, et al: Hypermethylation of the p14 (ARF) gene in ulcerative colitis-associated colorectal carcinogenesis. Cancer Res 62: 1148-1151, 2002.

6. Issa JP, Ahuja N, Toyota M, Bronner MP and Brentnall TA: Accelerated age-related $\mathrm{CpG}$ island methylation in ulcerative colitis. Cancer Res 61: 3573-3577, 2001.

7. Bian YS, Osterheld MC, Fontolliet C, Bosman FT and Benhattar J: p16 inactivation by methylation of the CDKN2A promoter occurs early during neoplastic progression in Barrett's esophagus. Gastroenterology 122: 1113-1121, 2002.

8. Wong DJ, Paulson TG, Prevo LJ, et al: p16 (INK4a) lesions are common, early abnormalities that undergo clonal expansion in Barrett's metaplastic epithelium. Cancer Res 61: 8284-8289, 2001.

9. Kaneto H, Sasaki S, Yamamoto H, et al: Detection of hypermethylation of the p16(INK4A) gene promoter in chronic hepatitis and cirrhosis associated with hepatitis $\mathrm{B}$ or $\mathrm{C}$ virus. Gut 48: 372-377, 2001.

10. Oue N, Sentani K, Yokozaki H, Kitadai Y, Ito R and Yasui W: Promoter methylation status of the DNA repair genes hMLH1 and MGMT in gastric carcinoma and metaplastic mucosa. Pathobiology 69: 143-149, 2001.

11. Kang GH, Lee S, Lim JS and Jung HY: Profile of aberrant CpG island methylation along the multistep pathway of gastric carcinogenesis. Lab Invest 83: 635-641, 2003.

12. Maekita T, Nakazawa K, Mihara M, et al: High levels of aberrant DNA methylation in Helicobacter pylori-infected gastric mucosae and its possible association with gastric cancer risk. Clin Cancer Res 12: 989-995, 2006.

13. Tahara T, Arisawa T, Sibata T, et al: Risk prediction of gastric cancer by analysis of aberrant DNA methylation in non-neoplastic gastric epithelium. Digestion 75: 54-61, 2007.

14. Vallyathan V, Shi X and Castranova V: Reactive oxygen species: their relation to pneumoconiosis and carcinogenesis. Environ Health Perspect 106: 1151-1155, 1998.

15. Weitzman SA, Turk PW, Milkowski D and Kozlowski K: Free radical adducts induce alterations in DNA cytosine methylation. Proc Natl Acad Sci USA 91: 1261-1264, 1994.

16. Ishii $\mathrm{T}$, Itoh $\mathrm{K}$, Takahashi $\mathrm{S}$, et al: Transcription factor Nrf2 coordinately regulates a group of oxidative stress-inducible genes in macrophages. J Biol Chem 275: 16023-16029, 2000.

17. Cho HY, Jedlicka AE, Reddy SP, Zhang LY, Kensler TW and Kleeberger SR: Linkage analysis of susceptibility to hyperoxia. Nrf2 is a candidate gene. Am J Respir Cell Mol Biol 26: 42-51, 2002.

18. Cho HY, Jedlicka AE, Reddy SP, et al: Role of NRF2 in protection against hyperoxic lung injury in mice. Am J Respir Cell Mol Biol 26: 175-182, 2002.

19. Yamamoto T, Yoh K, Kobayashi A, et al: Identification of polymorphisms in the promoter region of the human NRF2 gene. Biochem Biophys Res Commun 321: 72-79, 2004.

20. Arisawa T, Tahara T, Shibata T, et al: The relationship between Helicobacter pylori infection and promoter polymorphism of the Nrf2 gene in chronic gastritis. Int J Mol Med 19: 143-148, 2007.

21. Arisawa T, Tahara T, Shibata T, et al: Nrf2 gene promoter polymorphism is associated with ulcerative colitis in Japanese population. Hepatogastroenterology (In press).

22. Rizos H, Darmanian AP, Mann GJ and Kefford RF: Two arginine rich domains in the p14ARF tumour suppressor mediate nucleolar localization. Oncogene 19: 2978-2985, 2000.

23. Tannapfel A, Busse C, Weinans L, et al: INK4a-ARF alterations and p53 mutations in hepatocellular carcinomas. Oncogene 20: 7104-7109, 2001.
24. Toyota M, Ahuja N, Suzuki H, et al: Aberrant methylation in gastric cancer associated with the $\mathrm{CpG}$ island methylator phenotype. Cancer Res 59: 5438-5442, 1999.

25. Kang GH, Shim YH, Jung HY, Kim WH, Ro JY and Rhyu MG: $\mathrm{CpG}$ island methylation in premalignant stages of gastric carcinoma. Cancer Res 61: 2847-2851, 2001.

26. Pestov DG, Strezoska Z and Lau LF: Evidence of p53-dependent cross-talk between ribosome biogenesis and the cell cycle: effects of nucleolar protein Bop1 on G(1)/S transition. Mol Cell Biol 21: 4246-4255, 2001.

27. Polat A, Cinel L, Dusmez D, Aydin O and Egilmez R: Expression of cell-cycle related proteins in Helicobacter pylori gastritis and association with gastric carcinoma. Neoplasma 49: 95-100, 2002.

28. Kurosawa A, Miwa H, Hirose M, Tsune I, Nagahara A and Sato N: Inhibition of cell proliferation and induction of apoptosis by Helicobacter pylori through increased phosphorylated p53, p21 and Bax expression in endothelial cells. J Med Microbiol 51: 385-391, 2002.

29. Issa JP: GpG-island methylation in aging and cancer. Curr Top Microbiol Immunol 249: 101-118, 2000.

30. Fujii S, Tominaga K, Kitajima K, et al: Methylation of the oestrogen receptor gene in non-neoplastic epithelium as a marker of colorectal neoplasia risk in longstanding and extensive ulcerative colitis. Gut 54: 1287-1292, 2005.

31. Kang GH, Lee HJ, Hwang KS, Lee S, Kim JH and Kim JS: Abberant $\mathrm{CpG}$ island hypermethylation of charonic gastritis, in relation to aging, gender, intestinal metaplasia, and chronic inflammation. Am J Pathol 163: 1551-1556, 2003.

32. To KF, Leung WK, Lee TL, et al: Promoter hypermethylation of tumor-related genes in gastric intestinal metaplasia of patients with and without gastric cancer. Int J Cancer 102: 623-628, 2002.

33. Waki T, Tamura G, Tsuchiya T, Sato K, Nishizuka S and Motoyama T: Promoter methylation status of E-cadherin, hMLH1, and p16 genes in non-neoplastic gastric epithelia. Am J Pathol 161: 399-403, 2002.

34. Cerutti PA and Trump BF: Inflammation and oxidative stress in carcinogenesis. Cancer Cells 3: 1-7, 1991.

35. Burdon RH: Superoxide and hydrogen peroxide in relation to mammalian cell proliferation. Free Radic Biol Med 18: 775-794, 1995.

36. Meyer-ter-Vehn T, Covacci A, Kist M and Pahl HL: Helicobacter pylori activates mitogen-activated protein kinase cascades and induces expression of the proto-oncogenes c-fos and c-jun. J Biol Chem 275: 16064-16072, 2000

37. Seo JH, Lim JW, Kim H and Kim KH: Helicobacter pylori in a Korean isolate activates mitogen-activated kinase, AP-1 and NF- $\mathrm{B}$ B and induces chemokine expression in gastric epithelial AGS cells. Lab Invest 84: 49-62, 2004.

38. Weitzman SA, Lee RM and Ouellette AJ: Alterations in c-abl gene methylation in cells transformed by phagocyte-generated oxidants. Biochem Biophys Res Commun 158: 24-30, 1989.

39. Valle J, Kekki M, Sipponen P, Ihamaki T and Siurala M: Longterm course and consequences of Helicobacter pylori gastritis. Results of a 32-year follow-up study. Scand J Gastroenterol 31: 546-550, 1996.

40. Asaka M, Sugiyama T, Nobuta A, Kato M, Takeda H and Graham DY: Atrophic gastritis and intestinal metaplasia are strongly related to Helicobacter pylori infection and not to aging in Japan: results of a large multi-center study. Helicobacter 6: 294-299, 2001

41. Nakamura A, Park A, Nagata K, et al: Oxidative cellular damage associated with transformation of Helicobacter pylori from a bacillary to a coccoid form. Free Radic Biol Med 28: 1611-1618, 2000

42. Naito Y and Yoshikawa T: Molecular and cellular mechanisms involved in Helicobacter pylori-induced inflammation and oxidative stress. Free Radic Biol Med 33: 323-336, 2002.

43. Iida S, Akiyama Y, Nakajima T, et al: Alterations and hypermethylation of the p14(ARF) gene in gastric cancer. Int J Cancer 87: 654-658, 2000. 